\title{
Sistem Penilaian Karakteristik Anjing Menggunakan Metode Weighted Product
}

\section{Dog Characteristics Assessment System Using Weighted Product Method}

\author{
Christine $^{* 1}$, Halim Agung ${ }^{2}$ \\ 1,2,3 Magister Teknik Informatika, Universitas AMIKOM, Yogyakarta \\ E-mail: *11 christinemulia@gmail.com,,2hagung@bundamulia.ac.id
}

\begin{abstract}
Abstrak
Anjing merupakan hewan yang paling banyak populasinya di tahun 2016 menurut survey populasi hewan kesayangan oleh asosiasi pembuat makanan hewan di Inggris (PFMA). Dengan banyaknya jenis anjing dan perbedaan karakteristik, tidak semua manusia dapat memilih jenis anjing yang sesuai dengan situasi dan kondisi mereka. Maka dari itu sistem penilaian karateristik anjing dibuat yang bertujuan untuk memudahkan user dalam memilih jenis anjing yang sesuai dengan situasi dan kondisi user tersebut. Sistem ini dibuat dengan menggunakan metode weighted product karena metode ini lebih efisien dibandingkan metode lain yang termasuk dalam penyelesaian masalah MADM (Multi Attibute Decision Making). Sistem ini dibuat berdasarkan data anjing yang terdaftar di American Kennel Club. Variabel-variabel yang terdapat dalam sistem ini meliputi kategori kelompok, lingkungan yang cocok, level energi, kerontokan bulu, tingkat kesulitan grooming, tingkat kepatuhan, size anjing, dan seringnya gonggongan. Hasil yang didapatkan dari sistem penilaian ini adalah 20 dari 30 pengujian sesuai dengan perhitungan manual. Sehingga tingkat kecocokan dari metode weighted product adalah 67\%. Kesimpulan yang didapat dari penilitian ini adalah metode weighted product cukup efisien untuk diterapkan dalam sistem penilaian karakteristik anjing.
\end{abstract}

Kata Kunci - Rekomendasi Jenis Anjing, Weighted Product, Memilih Anjing, Karakteristik, Sistem Penilaian.

\begin{abstract}
The dog is the most populous animal in the year 2016 according to a survey of pets population by the association of animal feed makers in the UK (PFMA). With many dog breeds and characteristic differences, not all humans can choose the type of dog that suits their circumstances. Therefore, the system of characteristic assessment of dogs made that aims to facilitate the user in selecting the type of dog that suits the situation and condition of the user. This system is made using the weighted product method because this method is more efficient than other methods which are included in solving the MADM (Multi Attibute Decision Making) problem. This system is based on dog data registered with American Kennel Club. The variables contained in this system include group categories, suitable environments, energy levels, shedding, grooming difficulty level, adherence level, dog size, and frequent barking. The results obtained from this scoring system are 20 out of 30 tests according to manual calculations. So the match rate of weighted product method is $67 \%$. The conclusion of this research is that the weighted product method is efficient enough to be applied in the dog's characteristic rating system.
\end{abstract}

Keywords - Dog's Breed Recomendation, Weighted Product, Choosing Dog, Characteristic, Scoring System. 


\section{PENDAHULUAN}

Anjing merupakan hewan yang paling banyak populasinya di tahun 2016 menurut survey populasi hewan kesayangan oleh asosiasi pembuat makanan hewan di Inggris (PFMA)[1]. Anjing memiliki banyak jenis, dan memiliki keahlian dan karakteristik yang berbeda. Dengan banyaknya jenis anjing dan perbedaan karakteristik, tidak semua manusia dapat memilih jenis anjing yang sesuai dengan situasi dan kondisi mereka. Sekarang ini, banyak masyarakat memilih anjing untuk dipelihara hanya dengan melihat fisiknya saja tidak mempertimbangkan karakteristik dari anjing jenis tersebut. Beberapa kasus tentang anjing menyakiti maupun membunuh majikannya, telah beberapa kali terjadi. Dari banyak faktor yang mendukung terjadinya itu salah satunya adalah pemilik tersebut tidak mempertimbangkan karakteristik anjing tersebut, lingkungan yang dibutuhkan anjing tersebut, dan lain-lain. Kasus yang paling hangat adalah kejadian anjing pitbull yang menggigit anak majikannya hingga tewas di Malang. Anjing pitbull sendiri, memang dikenal dengan karakter pemberani, kuat, dan penyayang dan sering digunakan sebagai guard dog. Namun pitbull juga memiliki karakteristik one-man dog yakni anjing tersebut hanya menurut terhadap satu orang saja. Di luar sana, anjing pitbull sendiri memang dikenal juga sebagai babysitter dog, mereka dikenal sangat menyayangi anak kecil bahkan bisa menjaganya. Namun perlu diingat, dengan memiliki karakteristik seperti di atas bermain dengan anak kecil pun harus tetap diawasi. Tujuan dari penelitian ini adalah membuat sistem berbasis web yang memiliki kemampuan untuk memberikan informasi data jenis-jenis anjing dan penilaian karakteristik anjing kepada user.

Adapun ruang lingkup yang akan dibahas dalam penelitian ini adalah jenis anjing yang terdaftar di American Kennel Club dan faktor-faktor yang digunakan sebagai pertimbangan: Kategori kelompok, lingkungan yang cocok, level energi, kerontokan bulu, tingkat kesulitan grooming, tingkat kepatuhan, size anjing, seringnya gonggongan.

Dalam melakukan penulisan ini perlu diberikan beberapa tinjauan pustaka dan landasan teori sebagai dasar penelitian. Dalam penelitian oleh Aziz Ahmadi dan Dian Tri Wiyanti menerapkan metode weighted product untuk menentukan penerima bantuan langsung masyarakat di perdesaan [2], Dengan kata lain, Cokrokembang, Cangkring, Wonoasri, Ngadirojo, dan Pagerejo akan terpilih sebagai desa dengan prioritas tertinggi untuk mendapatkan BLM dari sekian alternatif desa pengusul. Dalam penelitian oleh Heru Supriyono dan Chintya Purnama Sari, metode weighted product diimplementasikan untuk pemilihan rumah tinggal [3]. Dari hasil pengujian dan pembahasan dapat disimpulkan bahwa metode weighted product telah berhasil diimplementasikan dalam pemilihan rumah tinggal dengan berdasarkan 11 faktor kriteria yang digunakan.

American Kennel Club adalah asosiasi anjing terbesar di Amerika Serikat. AKC (American Kennel Club) mengklasifikasikan anjing ke dalam 7 kategori (Dog Breed Groups) berdasarkan fungsi anjing [4].

1. Herding. Di banyak bagian dunia, herding dog masih tetap digunakan untuk mengumpulkan, menggiring dan melindungi ternak, fungsi yang sudah mereka lakukan sejak jaman prasejarah. Namun saat ini, beberapa ras herding dog seperti Herder/German shepherd dog, biasanya dilatih untuk tugas polisi dan tugas keamanan. Ras lain seperti Border collie, unggul dalam event kompetisi anjing. Karena loyalitas dan kecerdasan yang luar biasa, herding dog juga digunakan sebagai anjing peliharaan rumah dan anjing pengawas.

2. Hound. Kategori bagi anjing-anjing pemburu yang unggul. Kategori anjing kelompok ini tidak ganas, mereka hanya memburu hewan-hewan yang merugikan manusia.

3. Non-Sporting. Pada dasarnya adalah ras anjing yang beragam yang tidak termasuk dari kelompok lain. Keturunan dari kelompok anjing Non-sporting adalah kumpulan bervariasi dalam hal ukuran, bulu, kepribadian dan penampilan secara keseluruhan.

4. Sporting. Kelompok anjing ini dikembangbiakkan untuk kegiatan aktif seperti berburu dan kegiatan lapangan lainnya. Bagi pemilik anjing sporting perlu menyadari bahwa sebagian besar membutuhkan latihan yang teratur dan menyegarkan.

5. Terrier. Leluhur kaum terrier adalah para pengontrol hama berupa hewan pengerat. Ukuran yang relatif kecil memungkinkan mereka masuk memburu ke dalam celah sempit. Mereka 
cenderung tidak toleran pada anjing lain dan sangat energik. Sebagian besar terrier memiliki bulu lurus yang memerlukan perawatan khusus yang dikenal sebagai stripping untuk menjaga penampilan yang khas. Secara umum, kelompok anjing ini membuat hewan peliharaan menjadi lebih menarik, tetapi untuk itu membutuhkan pemilik dengan tekad untuk menyesuaikan karakter anjing tersebut.

6. Toy. Kategori ini dibiakkan untuk fungsi-fungsi yang tidak serius. Ukurannya relatif kecil sehingga untuk perawatan dan kebutuhan ruang dan pakan dalam skala lebih kecil.

7. Working. Kelompok ini dibiakkan untuk melakukan pekerjaan seperti menjaga rumah, menarik kereta dan melakukan penyelamatan korban bencana alam. Anjing jenis ini cocok sebagai hewan peliharaan untuk keluarga, berdasarkan ukuran dan karakternya anjing ini membutuhkan latihan yang khusus.

HTML adalah singkatan Hypertext Markup Language, merupakan file teks yang ditulis menggunakan aturan-aturan kode tertentu untuk kemudian disajikan ke user melalui suatu aplikasi web browser [5][6]. PHP adalah salah satu Bahasa pemrograman skrip yang dirancang untuk membangun aplikasi web [5]. PHP adalah singkatan dari Perl Hypertext Preprocessor adalah kode atau skrip yang akan dieksekusi pada server side [7]. MySQL merupakan turunan dari salah satu konsep utama dalam basisdata sejak lama, yaitu SQL (Structured Query Language). SQL adalah sebuah konsep pengoperasian basis data terutama untuk proses seleksi, pemasukan, pengubahan dan penghapusan data yang dimungkinkan dapat dikerjakan dengan mudah dan otomatis [7].

Metode weighted product adalah metode untuk pengambilan keputusan berdasarkan besarnya nilai preferensi yang dihitung berdasarkan pada nilai variabel yang digunakan yang dipangkatkan dengan bobotnya. Semakin besar nilai preserensi suatu alternatif solusi maka alternatif solusi itu semakin disukai. Besarnya nilai preferensi dihitung dengan persamaan 1 sebagai berikut [8]:

$$
S_{i}=\pi_{j-i}^{n} X_{i j} W^{j}
$$

Dengan Si adalah nilai preferensi alteratif ke-i, $i=1,2,3, \ldots$ m adalah indeks alternatif solusi yang tersedia, jn 3,....2,1,= adalah indeks faktor yang dipertimbangkan dalam proses pengambilan keputusan atau pemilihan alternatif solusi, w adalah bobot untuk masing-masing faktor yang digunakan dalam proses pengambilan keputusan, $x_{j}$ adalah nilai variabel alternatif solusi ke-i untuk variabel ke-j. Dalam proses perhitungan nilai preferensi, w akan bernilai positif apabila faktor tersebut merupakan atribut keuntungan namun akan bernilai negatif jika merupakan atribut biaya. Sebelum digunakan, nilai bobot harus dinormalisasi terlebih dahulu sehingga $\sum \mathrm{W}_{\mathrm{j}}=1$ dengan menggunakan persamaan 2 sebagai berikut [8]:

$$
W_{j}=\frac{W_{j}}{\sum W_{j}}
$$

Skor akhir dari setiap alternatif solusi kemudian d hitung sebagai nilai normalisasi dengan persamaan 3 sebagai berikut [8]:

$$
V_{i}=\frac{S_{i}}{\sum S_{i}}
$$

\section{METODE PENELITIAN}

Sistem dirancang hanya untuk melakukan penilaian karakteristik anjing ras yang terdaftar di AKC (American Kennel Club), sistem tidak dapat digunakan untuk penilaian karakteristik anjing ras yang tidak terdaftar di AKC. Sistem ini akan dirancang agar dapat mengolah data-data karakteristik anjing, dan menghasilkan output berupa penilaian karakteristik anjing tersebut, sehingga sistem yang dibangun akan membantu user yang hendak memelihara anjing agar tidak terjadi kejadian-kejadian tidak diinginkan nantinya. Langkah kerja sistem secara umum adalah 
Admin memasukkan data-data karakteristik anjing, Sistem melakukan proses penilaian kualitas dengan metode Weighted Product sesuai dengan bobot yang dimasukkan oleh user, User mendapatkan hasil penilaian karakteristik anjing dan User memilih jenis anjing yang diinginkan, data lengkap mengenai anjing tersebut akan ditampilkan.

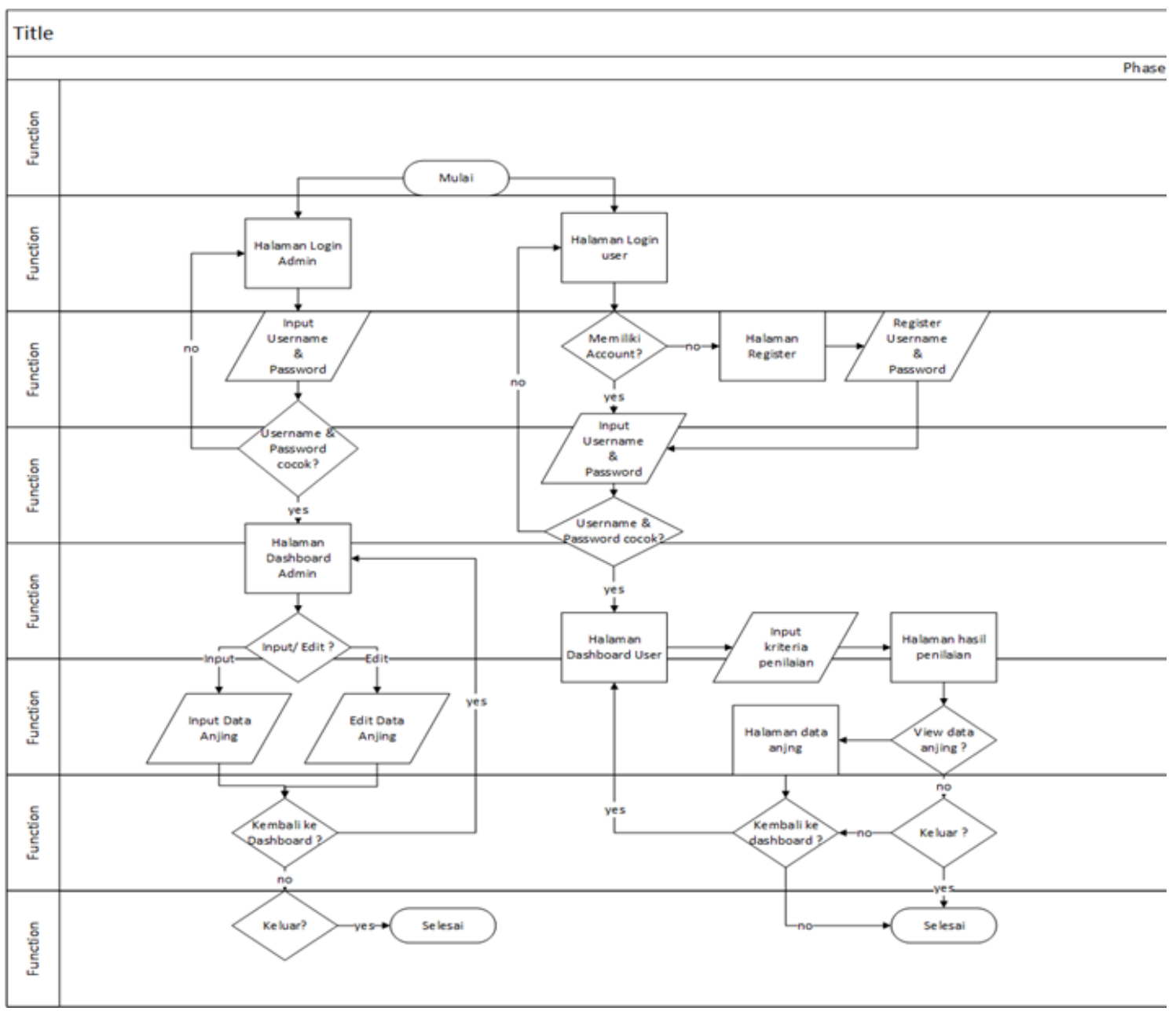

Gambar 1. Diagram Alir Penilaian Karakteristik Anjing

Berdasarkan Gambar 1 di atas dapat dilihat bahwa user memiliiki hak akses untuk mendapatkan penilaian karakteristik anjing, dimulai dengan proses registrasi user baru jika belum memiliki akun atau jika sudah memiliki akun dilanjutkan ke proses verifikasi user id dan password. Jika user id dan password sudah valid, maka sistem akan menampilkan dashboard user, selanjutnya user dapat memilih menu untuk memasukkan bobot penilaian karakteristik, user akan mendapatkan data penilaian karakteristik anjing berdasarkan bobot yang dimasukan sebelumnya, kemudian user dapat memilih untuk melihat data anjing atau tidak, jika tidak, maka user akan kembali ke halaman dashboard user.

Berdasarkan data-data yang telah dikumpulkan, didapatkan variabel-variabel yang dibutuhkan dalam perancangan sistem penerapan metode Weighted Product dalam penilaian karakteristik anjing adalah:

1. Kategori kelompok. Variabel kategori kelompok merupakan variabel tambahan yang digunakan dalam penilaian karakteristik anjing.

2. Lingkungan yang cocok. Variabel lingkungan yang cocok merupakan variabel tambahan yang digunakan dalam penilaian karakteristik anjing.

3. Level energi. Variabel level energi merupakan variabel yang digunakan dalam perhitungan yang menentukan penilaian karakteristik anjing dalam level energi. 
4. Kerontokan bulu. Variabel kerontokan bulu merupakan variabel yang digunakan dalam perhitungan yang menentukan penilaian karakteristik anjing dalam kerontokan bulu.

5. Tingkat kesulitan grooming. Variabel tingkat kesulitan grooming merupakan variabel yang digunakan dalam perhitungan yang menentukan penilaian karakteristik anjing dalam tingkat kesulitan grooming.

6. Tingkat Kepatuhan. Variabel tingkat kepatuhan merupakan variabel yang digunakan dalam perhitungan yang menentukan penilaian karakteristik anjing dalam tingkat kepatuhan.

7. Size anjing. Variabel size anjing merupakan variabel yang digunakan dalam perhitungan yang menentukan penilaian karakteristik anjing dalam size anjing.

8. Seringnya gonggongan. Variabel seringnya gonggongan merupakan variabel yang digunakan dalam perhitungan yang menentukan penilaian karakteristik anjing dalam seringnya gonggongan.

Dari variabel-variabel tersebut, masing-masing variabel kriteria, dibuat suatu rating tingkatan berdasarkan nilai bobot yang telah ditentukan ke dalam bilangan fuzzy. Rating kecocokan setiap nilai kriteria adalah Sangat Rendah $=1$, Rendah $=2$, Rata-rata $=3$, Tinggi $=4$ dan Sangat Tinggi $=5$.

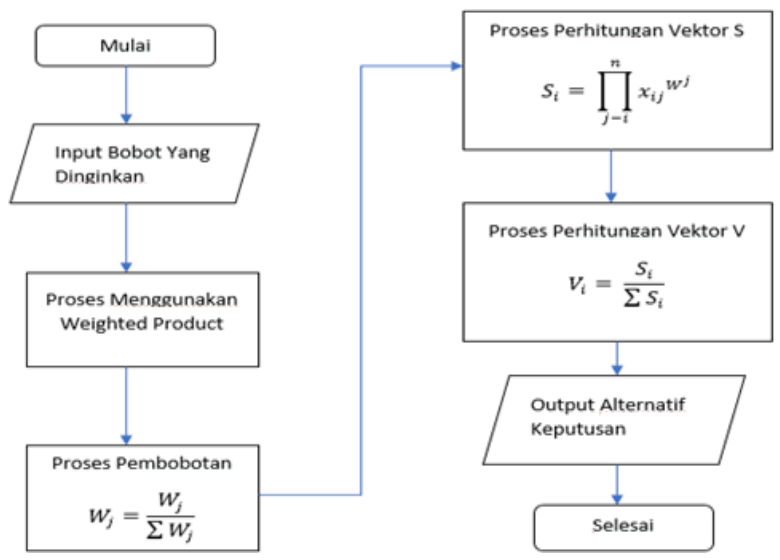

Gambar 2. Diagram Alir Metode Weighted Product

Pada sistem ini penggunaan metode Weighted Product perhitungannya dimulai dengan user memasukan nilai bobot yang diinginkan, kemudian sistem akan melakukan proses perhitungan dengan metode Weighted Product, dan menampilkan hasilnya kepada user. Proses Pembobotan pada Gambar 2 yaitu user menginginkan anjing dengan kelompok non-sporting, lingkungan apartment dog, level energi (rendah), kerontokan bulu (rendah), tingkat kesulitan grooming (rendah), tingkat kepatuhan (tinggi), size anjing (sedang), dan tingkat gonggongan (tinggi). Setelah data anjing disaring berdasarkan variabel lingkungan dan kelompok, terdapat 7 data anjing yaitu Bichon Frise, Boston Terrier, Bulldog, Chow Chow, Cotton de Tulear, Dogo Argentino dan French Bulldog. Data karakteristik dari 7 anjing dapat dilihat dari Tabel 1 dan Tabel 2.

Tabel 1. Data Karakter Jenis Anjing (American Kennel Club)

\begin{tabular}{|l|l|l|l|l|l|l|}
\hline Jenis Anjing & $\begin{array}{l}\text { Level } \\
\text { Energi }\end{array}$ & $\begin{array}{l}\text { Kerontokan } \\
\text { Bulu }\end{array}$ & $\begin{array}{l}\text { Tingkat } \\
\text { Kesulitan } \\
\text { Grooming }\end{array}$ & $\begin{array}{l}\text { Tingkat } \\
\text { Kepatuhan }\end{array}$ & $\begin{array}{l}\text { Size } \\
\text { Anjing }\end{array}$ & $\begin{array}{l}\text { Seringnya } \\
\text { Gonggongan }\end{array}$ \\
\hline Bichon Frise & Tinggi & Sangat Rendah & Sangat Tinggi & Sangat Tinggi & Kecil & Rata-rata \\
\hline Boston Terrier & Rata-rata & Rendah & Rendah & Sangat Tinggi & Kecil & Sangat Rendah \\
\hline Bulldog & Rendah & Rata-rata & Rendah & Tinggi & Sedang & Sangat Rendah \\
\hline Chow Chow & Rata-rata & Rata-rata & Tinggi & Rendah & Sedang & Sangat Rendah \\
\hline Cotton de Tulear & Tinggi & Sangat Rendah & Tinggi & Tinggi & Kecil & Rata-rata \\
\hline Dogo Argentino & Tinggi & Rendah & Rendah & Tinggi & Besar & Rata-rata \\
\hline French Bulldog & Rata-rata & Rata-rata & Rendah & Tinggi & Kecil & Sangat Rendah \\
\hline
\end{tabular}


Tabel 2. Data Karakter Jenis Anjing yang Sudah Dikonversikan

\begin{tabular}{|l|l|l|l|l|l|l|}
\hline Jenis Anjing & $\begin{array}{l}\text { Level } \\
\text { Energi }\end{array}$ & $\begin{array}{l}\text { Kerontokan } \\
\text { Bulu }\end{array}$ & $\begin{array}{l}\text { Tingkat } \\
\text { Kesulitan } \\
\text { Grooming }\end{array}$ & $\begin{array}{l}\text { Tingkat } \\
\text { Kepatuhan }\end{array}$ & $\begin{array}{l}\text { Size } \\
\text { Anjing }\end{array}$ & $\begin{array}{l}\text { Seringnya } \\
\text { Gonggongan }\end{array}$ \\
\hline Bichon Frise & 4 & 1 & 5 & 5 & 2 & 3 \\
\hline Boston Terrier & 3 & 2 & 2 & 5 & 2 & 1 \\
\hline Bulldog & 2 & 3 & 2 & 4 & 3 & 1 \\
\hline Chow Chow & 3 & 3 & 4 & 2 & 3 & 1 \\
\hline Cotton de Tulear & 4 & 1 & 4 & 4 & 2 & 3 \\
\hline Dogo Argentino & 4 & 2 & 2 & 4 & 4 & 3 \\
\hline French Bulldog & 3 & 3 & 2 & 4 & 2 & 1 \\
\hline
\end{tabular}

$\mathrm{W}=$ energi (rendah) + kerontokan bulu (rendah) + kesulitan grooming (rendah) + kepatuhan (tinggi) + size (sedang) + gonggongan (tinggi) $=1+1+1+4+4+5=16$. Normalisasi Bobotnya yaitu W1 $=1 / 16=0.0265, \mathrm{~W} 2=1 / 16=0.0265, \mathrm{~W} 3=1 / 16=0.0265, \mathrm{~W} 4=4 / 16$ $=0.25$, W5 $=4 / 16=0.25$ dan W6 $=5 / 16=0.3125$. Dimana W1 merupakan variabel level energy, W2 merupakan variabel kerontokan bulu, W3 merupakan variabel tingkat kesulitan grooming, W4 merupakan variabel tingkat kepatuhan, W5 merupakan variabel size anjing dan W6 merupakan variabel seringnya gonggongan.

\section{HASIL DAN PEMBAHASAN}

Secara manual, perhitungan yang dilakukan menggunakan rumus yang terdapat di persamaan 1 yaitu perhitungan vektor $S, S_{1}=\left(4^{0.0265}\right)\left(1^{0.0265}\right)\left(5^{0.0265}\right)\left(5^{0.25}\right)\left(2^{0.25}\right)\left(3^{0.3125}\right)=2.708, S_{2}$ $=\left(3^{0.0265}\right)\left(2^{0.0265}\right)\left(2^{0.0265}\right)\left(5^{0.25}\right)\left(2^{0.25}\right)\left(1^{0.3125}\right)=1.895, \mathrm{~S}_{3}=\left(2^{0.0265}\right)\left(3^{0.0265}\right)\left(2^{0.0265}\right)\left(4^{\wedge 0.25}\right)\left(3^{0.25}\right)$ $\left(1^{0.3125}\right)=1.984, \mathrm{~S}_{4}=\left(3^{0.0265}\right)\left(3^{0.0265}\right)\left(4^{0.0265}\right)\left(2^{0.25}\right)\left(3^{0.25}\right)\left(1^{0.3125}\right)=1.718, \mathrm{~S}_{5}=\left(4^{0.0265}\right)\left(1^{0.0265}\right)$ $\left(4^{0.0265}\right)\left(4^{0.25}\right)\left(2^{0.25}\right)\left(3^{0.3125}\right)=1.807, \mathrm{~S}_{6}=\left(4^{0.0265}\right)\left(2^{0.0265}\right)\left(2^{0.0265}\right)\left(4^{0.25}\right)\left(4^{0.25}\right)\left(3^{0.3125}\right)=3.027$ dan $S_{7}=\left(3^{0.0265}\right)\left(3^{0.0265}\right)\left(2^{0.0265}\right)\left(4^{0.25}\right)\left(2^{0.25}\right)\left(1^{0.3125}\right)=1.812$, Maka hasil yang didapat dapat dilihat pada Tabel 3.

Dimana S1 merupakan Bichon Frise, S2 merupakan Boston Terrier, S3 merupakan Bulldog. S4 merupakan Chow Chow, S5 merupakan Cotton de Tulear, S6 merupakan Dogo Argentino dan S7 merupakan French Bulldog. Untuk proses perhitungan vektor V dengan menggunakan rumus yang terdapat di persamaan 3 adalah Vektor $\mathrm{V}_{1}=2.708 /(2.708+1.895+$ $1.984+1.718+1.807+3.027+1.812)=2.708 / 14.951=0.181, \mathrm{~V}_{2}=1.895 /(2.708+1.895+$ $1.984+1.718+1.807+3.027+1.812)=1.895 / 14.951=0.126, V_{3}=1.984 /(2.708+1.895+$ $1.984+1.718+1.807+3.027+1.812)=1.984 / 14.951=0.132, \mathrm{~V}_{4}=1.718 /(2.708+1.895+$ $1.984+1.718+1.807+3.027+1.812)=1.718 / 14.951=0.114, V_{5}=1.807 /(2.708+1.895+$ $1.984+1.718+1.807+3.027+1.812)=1.807 / 14.951=0.120, V_{6}=3.027 /(2.708+1.895+$ $1.984+1.718+1.807+3.027+1.812)=3.027 / 14.951=0.202, \mathrm{~V}_{7}=1.812 /(2.708+1.895+$ $1.984+1.718+1.807+3.027+1.812)=1.812 / 14.951=0.121$, Maka hasil yang didapat dapat dilihat pada Tabel 4.

Tabel 3. Nilai Vektor S

\begin{tabular}{|l|c|}
\hline $\mathrm{S}_{\mathrm{i}}$ & Nilai $\mathrm{S}_{1}$ \\
\hline $\mathrm{S}_{1}$ & 2.708 \\
\hline $\mathrm{S}_{2}$ & 1.895 \\
\hline $\mathrm{S}_{3}$ & 1.984 \\
\hline $\mathrm{S}_{4}$ & 1.718 \\
\hline $\mathrm{S}_{5}$ & 1.807 \\
\hline $\mathrm{S}_{6}$ & 3.027 \\
\hline $\mathrm{S}_{7}$ & 1.812 \\
\hline $\mathrm{S}_{7}$ & 1.812 \\
\hline
\end{tabular}

Tabel 4. Nilai Vektor V

\begin{tabular}{|c|c|}
\hline $\mathrm{V}_{\mathrm{i}}$ & Nilai Vi \\
\hline $\mathrm{V}_{1}$ & 0.181 \\
\hline $\mathrm{V}_{2}$ & 0.126 \\
\hline $\mathrm{V}_{3}$ & 0.132 \\
\hline $\mathrm{V}_{4}$ & 0.114 \\
\hline $\mathrm{V}_{5}$ & 0.120 \\
\hline $\mathrm{V}_{6}$ & 0.202 \\
\hline $\mathrm{V}_{7}$ & 0.121 \\
\hline
\end{tabular}


Citec Journal, Vol. 5, No. 1, November 2017 - Januari 2018

Dimana V1 merupakan Bichon Frise, V2 merupakan Boston Terrier, V3 merupakan Bulldog, V4 merupakan Chow Chow, V5 merupakan Cotton de Tulear, V6 merupakan Dogo Argentino dan V7 merupakan French Bulldog, Maka diperolehlah 5 terbesar Nilai Vi terbaik yang memiliki nilai tertinggi yang dapat dilihat pada Tabel 5, Tabel 6 dan Gambar 3.

Tabel 5. Lima Nilai Terbesar Vektor V

\begin{tabular}{|c|c|c|}
\hline $\mathrm{Vi}$ & Nilai Vi & Ranking \\
\hline $\mathrm{V}_{6}$ & 0.202 & 1 \\
\hline $\mathrm{V}_{1}$ & 0.181 & 2 \\
\hline $\mathrm{V}_{3}$ & 0.132 & 3 \\
\hline $\mathrm{V}_{2}$ & 0.126 & 4 \\
\hline $\mathrm{V}_{7}$ & 0.121 & 5 \\
\hline
\end{tabular}

Tabel 6. Perbandingan Bobot Penilaian dengan Hasil Penilaian Sistem

\begin{tabular}{|c|c|}
\hline Bobot Penilaian & Penilaian Sistem \\
\hline $\begin{array}{ll} & \text { Kelompok (non-sporting) } \\
\text { - } & \text { Lingkungan (apartment-dog) } \\
\text { - } & \text { Level Energi (rendah) } \\
\text { - } & \text { Tingkat Kesulitan Grooming (rendah) } \\
\text { - } & \text { Tingkat Kepatuhan (tinggi) } \\
\text { - } & \text { Size Anjing (sedang) } \\
\text { - } & \text { Tingkat Gonggongan (tinggi) }\end{array}$ & $\begin{array}{ll}\text { 1. } & \text { Dogo Argentino (17.44) } \\
\text { 2. } & \text { Bischon Frise (16.38) } \\
\text { 3. } & \text { Cotton de Tulear (15.96) } \\
\text { 4. } & \text { Bulldog (12.8) } \\
\text { 5. } & \text { Boston Terrier (12.56) } \\
\text { 6. } & \text { French Bulldog (12.5) } \\
\text { 7. } & \text { Chow Chow (12.37) }\end{array}$ \\
\hline
\end{tabular}

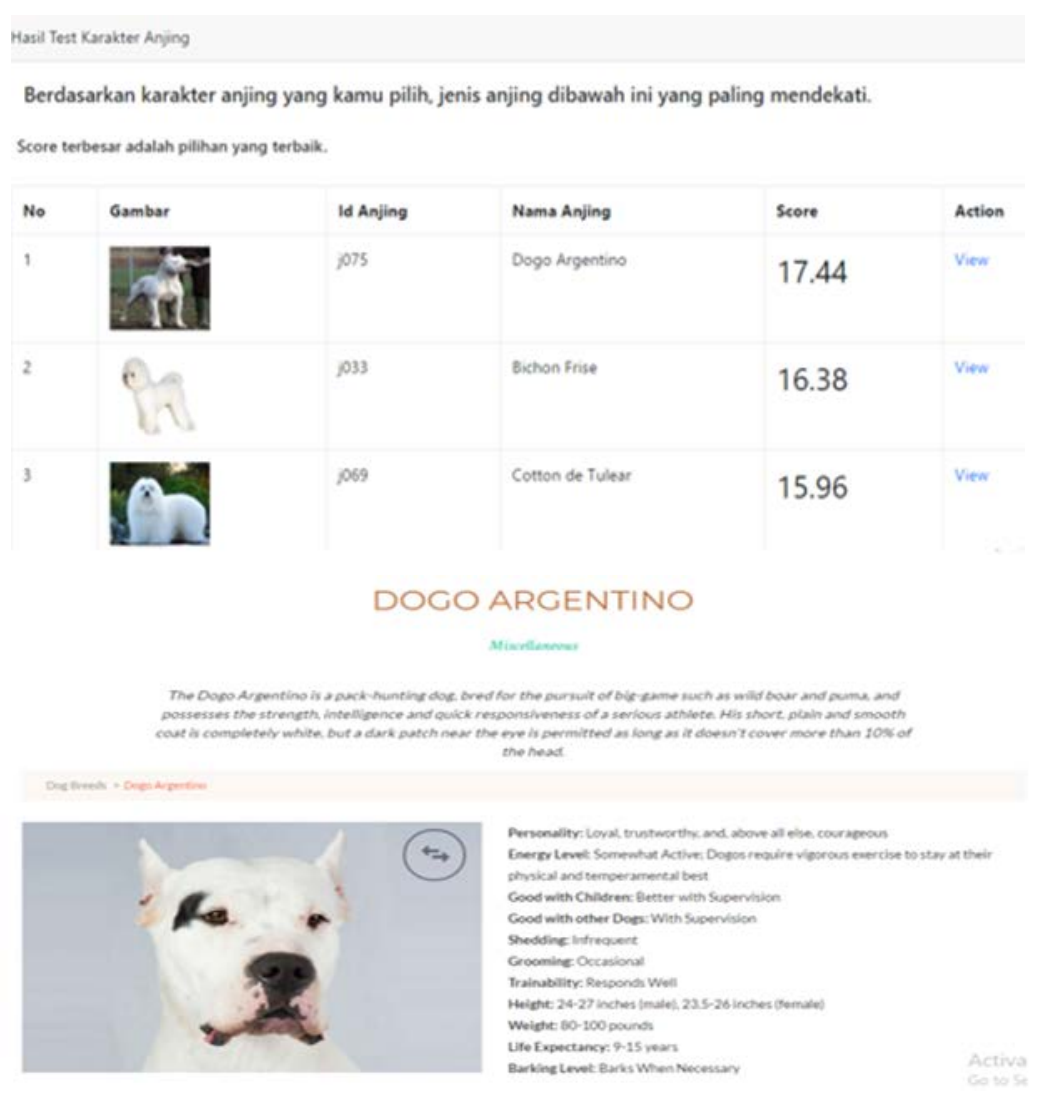

Gambar 3. Hasil Sistem 
Tabel 7. Perbandingan Kasus Hasil Algoritma dengan Hasil Manual

\begin{tabular}{|c|c|c|c|c|}
\hline No & Kasus & Hasil Algoritma & Hasil Manual & $\begin{array}{l}\text { Sesuai atau } \\
\text { tidak sesuai }\end{array}$ \\
\hline 1 & $\begin{array}{ll}\text { 1. } & \text { Kelompok (non-sporting) } \\
\text { 2. } & \text { Lingkungan (apartment-dog) } \\
\text { 3. Level energi (rendah) } \\
\text { 4. } & \text { Kerontokan bulu (rendah) } \\
\text { 5. } & \text { Tingkat kesulitan grooming (rendah) } \\
\text { 6. } & \text { Tingkat kepatuhan (tinggi) } \\
\text { 7. } & \text { Size anjing (sedang) } \\
\text { 8. } & \text { Tingkat gonggongan (tinggi) }\end{array}$ & Dogo Argentino & $\begin{array}{l}\text { Dogo } \\
\text { Argentino }\end{array}$ & Sesuai \\
\hline 2 & $\begin{array}{ll}\text { 1. } & \text { Kelompok (herding) } \\
\text { 2. } & \text { Lingkungan (apartment-dog) } \\
\text { 3. } & \text { Level energi (tinggi) } \\
\text { 4. } & \text { Kerontokan bulu (rata-rata) } \\
\text { 5. } & \text { Tingkat kesulitan grooming (rendah) } \\
\text { 6. } & \text { Tingkat kepatuhan (sangat tinggi) } \\
\text { 7. } & \text { Size anjing (kecil) } \\
\text { 8. } & \text { Tingkat gonggongan (tinggi) }\end{array}$ & $\begin{array}{l}\text { Finnish } \\
\text { Laphund }\end{array}$ & $\begin{array}{l}\text { Finnish } \\
\text { Laphund }\end{array}$ & Sesuai \\
\hline 3 & $\begin{array}{ll}\text { 1. } & \text { Kelompok (terrier) } \\
\text { 2. } & \text { Lingkungan (country-dog) } \\
\text { 3. } & \text { Level energi (tinggi) } \\
\text { 4. } & \text { Kerontokan bulu (rata-rata) } \\
\text { 5. } & \text { Tingkat kesulitan grooming (rendah) } \\
\text { 6. } & \text { Tingkat kepatuhan (sangat tinggi) } \\
\text { 7. } & \text { Size anjing (kecil) } \\
\text { 8. } & \text { Tingkat gonggongan (tinggi) }\end{array}$ & Airedale Terrier & Cesky Terrier & Tidak sesuai \\
\hline 4 & $\begin{array}{ll}\text { 1. } & \text { Kelompok (toy) } \\
\text { 2. } & \text { Lingkungan (apartment-dog) } \\
\text { 3. Level energi (rata-rata) } \\
\text { 4. } & \text { Kerontokan bulu (tinggi) } \\
\text { 5. } & \text { Tingkat kesulitan grooming (sangat } \\
& \text { tinggi) } \\
\text { 6. } & \text { Tingkat kepatuhan (rata-rata) } \\
\text { 7. } & \text { Size anjing (kecil) } \\
\text { 8. } & \text { Tingkat gonggongan (rendah) }\end{array}$ & Affenpinscher & Affenpinscher & Sesuai \\
\hline 5 & $\begin{array}{ll}\text { 1. } & \text { Kelompok (sporting) } \\
\text { 2. } & \text { Lingkungan (country-dog) } \\
\text { 3. } & \text { Level energi (sangat tinggi) } \\
\text { 4. } & \text { Kerontokan bulu (sangat rendah) } \\
\text { 5. } & \text { Tingkat kesulitan grooming (sangat } \\
& \text { rendah) } \\
\text { 6. } & \text { Tingkat kepatuhan (sangat tinggi) } \\
\text { 7. } & \text { Size anjing (besar) } \\
\text { 8. } & \text { Tingkat gonggongan (rata-rata) }\end{array}$ & $\begin{array}{l}\text { Irish Red and } \\
\text { White Setter }\end{array}$ & $\begin{array}{l}\text { Flat Coated } \\
\text { Retriver }\end{array}$ & Tidak Sesuai \\
\hline 6 & $\begin{array}{ll}\text { 1. } & \text { Kelompok (working) } \\
\text { 2. } & \text { Lingkungan (country-dog) } \\
\text { 3. } & \text { Level energi (tinggi) } \\
\text { 4. } & \text { Kerontokan bulu (tinggi) } \\
\text { 5. } & \text { Tingkat kesulitan grooming (tinggi) } \\
\text { 6. } & \text { Tingkat kepatuhan (tinggi) } \\
\text { 7. } & \text { Size anjing (sangat besar) } \\
\text { 8. } & \text { Tingkat gonggongan (sangat rendah) }\end{array}$ & Chinook & $\begin{array}{l}\text { Alaskan } \\
\text { Malamute }\end{array}$ & Tidak Sesuai \\
\hline
\end{tabular}


Citec Journal, Vol. 5, No. 1, November 2017 - Januari 2018

\begin{tabular}{|c|c|c|c|c|}
\hline No & Kasus & Hasil Algoritma & Hasil Manual & $\begin{array}{l}\text { Sesuai atau } \\
\text { tidak sesuai }\end{array}$ \\
\hline 7 & $\begin{array}{ll}\text { 1. } & \text { Kelompok (hound) } \\
\text { 2. } & \text { Lingkungan (country-dog) } \\
\text { 3. } & \text { Level energi (tinggi) } \\
\text { 4. } & \text { Kerontokan bulu (rata-rata) } \\
\text { 5. } & \text { Tingkat kesulitan grooming (tinggi) } \\
\text { 6. } & \text { Tingkat kepatuhan (tinggi) } \\
\text { 7. } & \text { Size anjing (sangat besar) } \\
\text { 8. } & \text { Tingkat gonggongan (tinggi) }\end{array}$ & $\begin{array}{l}\text { American } \\
\text { English } \\
\text { Coonhound }\end{array}$ & $\begin{array}{l}\text { Bluetick } \\
\text { Coonhound }\end{array}$ & Tidak Sesuai \\
\hline 8 & $\begin{array}{ll}\text { 1. } & \text { Kelompok (sporting) } \\
\text { 2. } & \text { Lingkungan (apartment-dog) } \\
\text { 3. } & \text { Level energi (rendah) } \\
\text { 4. } & \text { Kerontokan bulu (sangat rendah) } \\
\text { 5. } & \text { Tingkat kesulitan grooming (rata-rata) } \\
\text { 6. } & \text { Tingkat kepatuhan (sangat tinggi) } \\
\text { 7. } & \text { Size anjing (kecil) } \\
\text { 8. } & \text { Tingkat gonggongan (tinggi) }\end{array}$ & $\begin{array}{l}\text { English Cocker } \\
\text { Spaniel }\end{array}$ & English Setter & Tidak Sesuai \\
\hline 9 & $\begin{array}{ll}\text { 1. } & \text { Kelompok (terrier) } \\
\text { 2. } & \text { Lingkungan (country-dog) } \\
\text { 3. } & \text { Level energi (rendah) } \\
\text { 4. } & \text { Kerontokan bulu (rata-rata) } \\
\text { 5. } & \text { Tingkat kesulitan grooming (rata-rata) } \\
\text { 6. } & \text { Tingkat kepatuhan (sangat rendah) } \\
\text { 7. } & \text { Size anjing (besar) } \\
\text { 8. } & \text { Tingkat gonggongan (tinggi) }\end{array}$ & $\begin{array}{l}\text { Black Russian } \\
\text { Terrier }\end{array}$ & $\begin{array}{l}\text { Black Russian } \\
\text { Terrier }\end{array}$ & Sesuai \\
\hline 10 & $\begin{array}{ll}\text { 1. } & \text { Kelompok (non-sporting) } \\
\text { 2. } & \text { Lingkungan (country-dog) } \\
\text { 3. } & \text { Level energi (tinggi) } \\
\text { 4. } & \text { Kerontokan bulu (sangat rendah) } \\
\text { 5. } & \text { Tingkat kesulitan grooming (tinggi) } \\
\text { 6. } & \text { Tingkat kepatuhan (sangat rendah) } \\
\text { 7. } & \text { Size anjing (sedang) } \\
\text { 8. } & \text { Tingkat gonggongan (rata-rata }\end{array}$ & Finnish Spitz & Finnish Spitz & Sesuai \\
\hline 11 & $\begin{array}{ll}\text { 1. } & \text { Kelompok (hound) } \\
\text { 2. } & \text { Lingkungan (apartment-dog) } \\
\text { 3. } & \text { Level energi (rendah) } \\
\text { 4. } & \text { Kerontokan bulu (tinggi) } \\
\text { 5. } & \text { Tingkat kesulitan grooming (tinggi) } \\
\text { 6. } & \text { Tingkat kepatuhan (sangat rendah) } \\
\text { 7. } & \text { Size anjing (sedang) } \\
\text { 8. } & \text { Tingkat gonggongan (sangat tinggi) }\end{array}$ & Harrier & Harrier & Sesuai \\
\hline 12 & $\begin{array}{ll}\text { 1. } & \text { Kelompok (sporting) } \\
\text { 2. } & \text { Lingkungan (apartment-dog) } \\
\text { 3. } & \text { Level energi (rendah) } \\
\text { 4. } & \text { Kerontokan bulu (rendah) } \\
\text { 5. } & \text { Tingkat kesulitan grooming (rata-rata) } \\
\text { 6. } & \text { Tingkat kepatuhan (rata-rata) } \\
\text { 7. } & \text { Size anjing (sedang) } \\
\text { 8. } & \text { Tingkat gonggongan (tinggi) }\end{array}$ & Gordon Setter & Barbet & Tidak Sesuai \\
\hline 13 & $\begin{array}{ll}\text { 1. } & \text { Kelompok (Toy) } \\
\text { 2. } & \text { Lingkungan (Country-dog) } \\
\text { 3. } & \text { Level energi (Sangat tinggi ) } \\
\text { 4. } & \text { Kerontokan bulu (Sangat tinggi) } \\
\text { 5. } & \text { Tingkat kesulitan grooming (rata-rata) } \\
\text { 6. } & \text { Tingkat kepatuhan (rata-rata) } \\
\text { 7. } & \text { Size anjing (sangat besar) } \\
\end{array}$ & Brussels Griffin & $\begin{array}{l}\text { Brussels } \\
\text { Griffin }\end{array}$ & Sesuai \\
\hline
\end{tabular}




\begin{tabular}{|c|c|c|c|c|}
\hline \multirow[t]{2}{*}{ No } & Kasus & \multirow[t]{2}{*}{ Hasil Algoritma } & \multirow[t]{2}{*}{ Hasil Manual } & \multirow{2}{*}{$\begin{array}{l}\text { Sesuai atau } \\
\text { tidak sesuai }\end{array}$} \\
\hline & 8. Tingkat gonggongan (sangat tinggi) & & & \\
\hline 14 & $\begin{array}{ll}\text { 1. } & \text { Kelompok (Non-sporting) } \\
\text { 2. } & \text { Lingkungan (apartement-dog) } \\
\text { 3. } & \text { Level energi (tinggi) } \\
\text { 4. } & \text { Kerontokan bulu (rendah) } \\
\text { 5. } & \text { Tingkat kesulitan grooming (tinggi) } \\
\text { 6. } & \text { Tingkat kepatuhan (sangat tinggi) } \\
\text { 7. } & \text { Size anjing (kecil) } \\
\text { 8. } & \text { Tingkat gonggongan (rata-rata) } \\
\end{array}$ & Bichon Frose & Bichon Frose & Sesuai \\
\hline 15 & $\begin{array}{ll}\text { 1. } & \text { Kelompok (Non-sporting) } \\
\text { 2. } & \text { Lingkungan (country-dog) } \\
\text { 3. } & \text { Level energi (tinggi) } \\
\text { 4. } & \text { Kerontokan bulu (sangat rendah) } \\
\text { 5. } & \text { Tingkat kesulitan grooming (tinggi) } \\
\text { 6. } & \text { Tingkat kepatuhan (tinggi) } \\
\text { 7. } & \text { Size anjing (kecil) } \\
\text { 8. } & \text { Tingkat gonggongan (rata-rata) }\end{array}$ & Finnish Spitz & Azawakh & Tidak Sesuai \\
\hline 16 & $\begin{array}{ll}\text { 1. } & \text { Kelompok (Non-sporting) } \\
\text { 2. } & \text { Lingkungan (country-dog) } \\
\text { 3. } & \text { Level energi (rata-rata) } \\
\text { 4. } & \text { Kerontokan bulu (sangat rendah) } \\
\text { 5. } & \text { Tingkat kesulitan grooming (rendah) } \\
\text { 6. } & \text { Tingkat kepatuhan (sangat tinggi) } \\
\text { 7. } & \text { Size anjing (besar) } \\
\text { 8. } & \text { Tingkat gonggongan (rendah) }\end{array}$ & $\begin{array}{l}\text { American } \\
\text { Eskimo Dog }\end{array}$ & $\begin{array}{l}\text { American } \\
\text { Eskimo Dog }\end{array}$ & Sesuai \\
\hline 17 & $\begin{array}{ll}\text { 1. } & \text { Kelompok (Hound) } \\
\text { 2. } & \text { Lingkungan (apartment-dog) } \\
\text { 3. } & \text { Level energi (rata-rata) } \\
\text { 4. } & \text { Kerontokan bulu (sangat tinggi) } \\
\text { 5. } & \text { Tingkat kesulitan grooming (sangat } \\
& \text { tinggi) } \\
\text { 6. } & \text { Tingkat kepatuhan (sangat tinggi) } \\
\text { 7. } & \text { Size anjing (besar) } \\
\text { 8. } & \text { Tingkat gonggongan (rendah) }\end{array}$ & Basset Hound & Basset Hound & Sesuai \\
\hline 18 & $\begin{array}{ll}\text { 1. } & \text { Kelompok (Hound) } \\
\text { 2. } & \text { Lingkungan (country-dog) } \\
\text { 3. } & \text { Level energi (rata-rata) } \\
\text { 4. } & \text { Kerontokan bulu (sangat tinggi) } \\
\text { 5. } & \text { Tingkat kesulitan grooming (sangat } \\
& \text { tinggi) } \\
\text { 6. } & \text { Tingkat kepatuhan (sangat tinggi) } \\
\text { 7. } & \text { Size anjing (besar) } \\
\text { 8. } & \text { Tingkat gonggongan (rendah) }\end{array}$ & Beagle & Bloodhound & Tidak Sesuai \\
\hline 19 & $\begin{array}{ll}\text { 1. } & \text { Kelompok (Hound) } \\
\text { 2. } & \text { Lingkungan (country-dog) } \\
\text { 3. } & \text { Level energi (rata-rata) } \\
\text { 4. } & \text { Kerontokan bulu (tinggi) } \\
\text { 5. } & \text { Tingkat kesulitan grooming (tinggi) } \\
\text { 6. } & \text { Tingkat kepatuhan (tinggi) } \\
\text { 7. } & \text { Size anjing (besar) } \\
\text { 8. } & \text { Tingkat gonggongan (sangat rendah) }\end{array}$ & Bloodhound & Bloodhound & Sesuai \\
\hline
\end{tabular}


Citec Journal, Vol. 5, No. 1, November 2017 - Januari 2018

ISSN: 2460-4259

\begin{tabular}{|c|c|c|c|c|}
\hline No & Kasus & Hasil Algoritma & Hasil Manual & $\begin{array}{l}\text { Sesuai atau } \\
\text { tidak sesuai }\end{array}$ \\
\hline 20 & $\begin{array}{ll}\text { 1. } & \text { Kelompok (Herding) } \\
\text { 2. } & \text { Lingkungan (country-dog) } \\
\text { 3. } & \text { Level energi (rata-rata) } \\
\text { 4. } & \text { Kerontokan bulu (tinggi) } \\
\text { 5. } & \text { Tingkat kesulitan grooming (tinggi) } \\
\text { 6. } & \text { Tingkat kepatuhan (tinggi) } \\
\text { 7. } & \text { Size anjing (besar) } \\
\text { 8. } & \text { Tingkat gonggongan (sangat rendah) }\end{array}$ & Beauceron & Beauceron & Sesuai \\
\hline 21 & $\begin{array}{ll}\text { 1. } & \text { Kelompok (Herding) } \\
\text { 2. } & \text { Lingkungan (Apartment-dog) } \\
\text { 3. } & \text { Level energi (rata-rata) } \\
\text { 4. } & \text { Kerontokan bulu (rata-rata) } \\
\text { 5. } & \text { Tingkat kesulitan grooming (rendah) } \\
\text { 6. } & \text { Tingkat kepatuhan (sangat tinggi) } \\
\text { 7. } & \text { Size anjing (kecil) } \\
\text { 8. } & \text { Tingkat gonggongan (rata-rata) } \\
\end{array}$ & $\begin{array}{l}\text { Bergamasco } \\
\text { Sheepdog }\end{array}$ & $\begin{array}{l}\text { Bergamasco } \\
\text { Sheepdog }\end{array}$ & Sesuai \\
\hline 22 & $\begin{array}{ll}\text { 1. } & \text { Kelompok (Sporting) } \\
\text { 2. } & \text { Lingkungan (Country-dog) } \\
\text { 3. } & \text { Level energi (tinggi) } \\
\text { 4. } & \text { Kerontokan bulu (tinggi) } \\
\text { 5. } & \text { Tingkat kesulitan grooming (rata-rata) } \\
\text { 6. } & \text { Tingkat kepatuhan (rata-rata) } \\
\text { 7. } & \text { Size anjing (sangat besar) } \\
\text { 8. } & \text { Tingkat gonggongan (sangat tinggi) }\end{array}$ & Irish Setter & $\begin{array}{l}\text { Irish Red and } \\
\text { White Setter }\end{array}$ & Tidak Sesuai \\
\hline 23 & $\begin{array}{ll}\text { 1. } & \text { Kelompok (Terrier) } \\
\text { 2. } & \text { Lingkungan (Apartment-dog) } \\
\text { 3. } & \text { Level energi (tinggi) } \\
\text { 4. } & \text { Kerontokan bulu (rata-rata) } \\
\text { 5. } & \text { Tingkat kesulitan grooming (tinggi) } \\
\text { 6. } & \text { Tingkat kepatuhan (rendah) } \\
\text { 7. } & \text { Size anjing (sangat besar) } \\
\text { 8. } & \text { Tingkat gonggongan (tinggi) }\end{array}$ & $\begin{array}{l}\text { American } \\
\text { Staffordshire } \\
\text { Terrier }\end{array}$ & $\begin{array}{l}\text { American } \\
\text { Staffordshire } \\
\text { Terrier }\end{array}$ & Sesuai \\
\hline 24 & $\begin{array}{ll}\text { 1. } & \text { Kelompok (Terrier) } \\
\text { 2. } & \text { Lingkungan (Apartment-dog) } \\
\text { 3. } & \text { Level energi (tinggi) } \\
\text { 4. } & \text { Kerontokan bulu (rata-rata) } \\
\text { 5. } & \text { Tingkat kesulitan grooming (tinggi) } \\
\text { 6. } & \text { Tingkat kepatuhan (rendah) } \\
\text { 7. } & \text { Size anjing (sangat besar) } \\
\text { 8. } & \text { Tingkat gonggongan (tinggi) } \\
\end{array}$ & $\begin{array}{l}\text { Dandie Dinmont } \\
\text { Terrier }\end{array}$ & $\begin{array}{l}\text { Dandie } \\
\text { Dinmont } \\
\text { Terrier }\end{array}$ & Sesuai \\
\hline 25 & $\begin{array}{ll}\text { 1. } & \text { Kelompok (Working) } \\
\text { 2. } & \text { Lingkungan (Country-dog) } \\
\text { 3. } & \text { Level energi (tinggi) } \\
\text { 4. } & \text { Kerontokan bulu (rata-rata) } \\
\text { 5. } & \text { Tingkat kesulitan grooming (sangat } \\
& \text { rendah) } \\
\text { 6. } & \text { Tingkat kepatuhan (sangat tinggi) } \\
\text { 7. } & \text { Size anjing (sangat besar) } \\
\text { 8. } & \text { Tingkat gonggongan (sangat tinggi) }\end{array}$ & Great Dane & Great Dane & Sesuai \\
\hline 26 & $\begin{array}{ll}\text { 1. } & \text { Kelompok (Working) } \\
\text { 2. } & \text { Lingkungan (Apartment-dog) } \\
\text { 3. Level energi (tinggi) } \\
\text { 4. }\end{array}$ & $\begin{array}{l}\text { Greater Swiss } \\
\text { Mountain Dog }\end{array}$ & $\begin{array}{l}\text { Greater Swiss } \\
\text { Mountain Dog }\end{array}$ & Sesuai \\
\hline
\end{tabular}




\begin{tabular}{|c|c|c|c|c|}
\hline No & Kasus & Hasil Algoritma & Hasil Manual & $\begin{array}{l}\text { Sesuai atau } \\
\text { tidak sesuai }\end{array}$ \\
\hline & $\begin{array}{l}\text { 5. Tingkat kesulitan grooming (sangat } \\
\text { rendah) } \\
\text { 6. Tingkat kepatuhan (sangat tinggi) } \\
\text { 7. Size anjing (sangat besar) } \\
\text { 8. Tingkat gonggongan (sangat tinggi) }\end{array}$ & & & \\
\hline 27 & $\begin{array}{ll}\text { 1. } & \text { Kelompok (Working) } \\
\text { 2. } & \text { Lingkungan (Apartment-dog) } \\
\text { 3. } & \text { Level energi (rata-rata } \\
\text { 4. } & \text { Kerontokan bulu (rendah) } \\
\text { 5. } & \text { Tingkat kesulitan grooming (tinggi) } \\
\text { 6. } & \text { Tingkat kepatuhan (tinggi) } \\
\text { 7. } & \text { Size anjing (sangat kecil) } \\
\text { 8. } & \text { Tingkat gonggongan (rata-rata) }\end{array}$ & Akita & Akita & Sesuai \\
\hline 28 & $\begin{array}{ll}\text { 1. } & \text { Kelompok (Working) } \\
\text { 2. Lingkungan (country-dog) } \\
\text { 3. Level energi (sangat tinggi) } \\
\text { 4. Kerontokan bulu (sangat rendah) } \\
\text { 5. Tingkat kesulitan grooming (sangat } \\
\text { tinggi) } \\
\text { 6. Tingkat kepatuhan (tinggi) } \\
\text { 7. } & \text { Size anjing (sedang) } \\
\text { 8. } & \text { Tingkat gonggongan (sangat tinggi) }\end{array}$ & Giant Schnauzer & $\begin{array}{l}\text { Giant } \\
\text { Schnauzer }\end{array}$ & Sesuai \\
\hline 29 & $\begin{array}{ll}\text { 1. } & \text { Kelompok (Sporting) } \\
\text { 2. Lingkungan (country-dog) } \\
\text { 3. Level energi (sangat tinggi) } \\
\text { 4. Kerontokan bulu (sangat rendah) } \\
\text { 5. Tingkat kesulitan grooming (sangat } \\
\text { tinggi) } \\
\text { 6. Tingkat kepatuhan (tinggi) } \\
\text { 7. Size anjing (sedang) } \\
\text { 8. }\end{array}$ & Boykin Spaniel & Brittany & Tidak Sesuai \\
\hline 30 & $\begin{array}{ll}\text { 1. } & \text { Kelompok (Sporting) } \\
\text { 2. Lingkungan (country-dog) } \\
\text { 3. Level energi (sangat tinggi) } \\
\text { 4. Kerontokan bulu (sangat rendah) } \\
\text { 5. Tingkat kesulitan grooming (sangat } \\
\text { tinggi) } \\
\text { 6. Tingkat kepatuhan (tinggi) } \\
\text { 7. } & \text { Size anjing (sedang) } \\
\text { 8. } & \text { Tingkat gonggongan (sangat tinggi) }\end{array}$ & Brittany & Brittany & Sesuai \\
\hline
\end{tabular}

Setelah dilakukan sebanyak 30 percobaan mendapatkan hasil yang sesuai dengan hasil manual sebanyak 20 percobaan, sehingga tingkat kesesuaian sistem ini 67\%. Penggunaan metode weighted product dalam pemilihan jenis anjing belum pernah diteliti sebelumnya, baik metodemetode sistem pendukung keputusan lainnya. Oleh karena itu penelitian ini unik dan belum pernah dibahas dan dapat membantu user dalam memilih jenis anjing yang cocok dengan situasi dan kondisi user. 


\section{KESIMPULAN}

Hasil yang diperoleh dalam penelitian ini adalah 20 dari 30 percobaan sesuai dengan hasil manual sehingga memiliki tingkat kesesuaian 67\%. Kesimpulan yang didapat dari penelitian ini adalah metode weighted product cukup efisien untuk diterapkan dalam sistem penilaian karakteristik anjing. Sistem penilaian karakteristik ini dapat membantu user dalam memilih jenis anjing yang memiliki karakteristik yang sesuai dengan situasi dan kondisi user sehingga dapat meminimalisir kecelakaan-kecelakaan yang disebabkan oleh kurangnya informasi mengenai jenis anjing tertentu.

\section{SARAN}

Sistem penilaian karakteristik anjing ini diharapkan akan menjadi lebih baik dengan beberapa saran yang dapat digunakan:

1. Penulis menyarankan untuk menambahkan beberapa kriteria dengan berdiskusi dengan beberapa pakar sehingga dihasilkan system yang lebih akurat.

2. Penulis menyarankan untuk menambah sumber data anjing dari berbagai sumber yang terpercaya misalnya pakar hewan dalam hal ini berkaitan dengan hewan anjing.

3. Penulis menyarankan untuk mencoba metode KNN dalam sistem penilaian karakteristik anjing.

\section{DAFTAR PUSTAKA}

[1] PFMA, Pet Food Manufacturers Association Pet Population, https://www.pfma.org.uk/ petpopulation-2016, diakses tanggal 9 Desember 2017.

[2] Ahmadi, A., Tri, W. D., 2014, Implementasi Weighted Product Dalam Penentuan Penerima Bantuan Langsung Masyarakat PNPM Mandiri Perdesaan, Seminar Nasional Aplikasi Teknologi Informasi (SNATI), Yogyakarta, 21 Juni 2014.

[3] Supriyono, H., Purnama, S. C., 2015, Pemilihan Rumah Tinggal Menggunakan Metode Weighted Product, Khazanah Informatika, Vol. I No. 1, Hal. 23-28.

[4] AKC, American Kennel Club All Dog Breeds, http://www.akc.org/dog-breeds/, diakses tanggal 16 Desember 2017

[5] Sutaji, D., 2012, Sistem Iventory Mini Market Dengan PHP dan JQuery, Lokomedia, Yogyakarta

[6] Rahardja, U., Handayani, I., Ningrum, A., 2017, Pemanfaatan Sistem iMe Berbasis Wordpress sebagai Official Site RCEP pada Perguruan Tinggi, CITEC Journal, Vol.4 No.3, Hal. 207-219

[7] Raharjo, B., 2012, Modul Pemograman Web HTML, PHP dan MYSQL, Modula, Bandung.

[8] Syaukani, M., Kusnanto, H., 2012, Pemodelan Sistem Pendukung Keputusan Kelompok Dengan Menggunakan Metode Fuzzy Weighted Product Untuk Diagnosis Penyakit Pneumonia, Jurnal Teknologi, Vol.5 No.1, Hal. 17-23

[9] Mulyani, E., Sugiharto, A., Agustian, R., 2016, Penyeleksian Siswa Partner Schulen der Zukunft dengan Metode Fuzzy Weighted Product (WP) di SMAN 3 Tasikmalaya, CITEC Journal, Vol.3 No.4 